\title{
IDENTIFIKASI Candida sp DALAM URINE PENDERITA DIABETES MELLITUS TIPE 2 DI PUSKESMAS NGEMPLAK 2 KABUPATEN SLEMAN YOGYAKARTA
}

\author{
Nurlaili Farida Muhajir ${ }^{1}$, Fitri Nadifah ${ }^{1}$, Desto Arisandi ${ }^{1,}$ Maria Susliyanti $^{2}$ \\ 1. Program Studi D3 Teknologi Laboratorium Medik, STIKES Guna Bangsa, Sleman-Indonesia \\ 2. Program Studi D3 Teknologi Laboratorium Medik, STIKES Guna Bangsa, Sleman-Indonesia \\ 3. Program Studi D3 Teknologi Laboratorium Medik, STIKES Guna Bangsa, Sleman-Indonesia \\ 4. Program Studi D3 Teknologi Laboratorium Medik, STIKES Guna Bangsa, Sleman-Indonesia
}

*Korespondensi: Nurlaili Farida Muhajir | STIKes Guna Bangsa | nurlailifarida@ gmail.com

\begin{abstract}
Abstrak
Pendahuluan: Jamur Candida $s p$ dapat berperan sebagai mikroorganisme yang bersifat patogen yaitu menimbulkan infeksi primer dan sekunder. Penderita diabetes mellitus (DM) dapat mengalami infeksi jamur tersebut karena mekanisme pertahanan alami tubuh yang rendah. Komplikasi yang terkait DM dapat meningkatkan risiko infeksi, peningkatan kadar gula dalam darah, jaringan, dan urine. Penelitian ini bertujuan untuk mengetahui keberadaan jamur Candida $s p$ dalam urine penderita diabetes mellitus tipe 2.

Metode Jenis penelitian ini adalah deskriptif dengan desain penelitian cross sectional. Jumlah sampel sebanyak 30 spesimen urine penderita diabetes mellitus tipe 2 dengan kriteria inklusi berjenis kelamin laki-laki dan perempuan, pasien adalah peserta program pengelolaan penyakit kronis (prolanis) di Puskesmas Ngemplak 2 Kabupaten Sleman Yogyakarta. Tahap pengumpulan data dilakukan pada bulan Juli 2019 di Puskesmas Ngemplak 2 Kabupaten Sleman Yogyakarta. Pemeriksaan jamur Candida sp dilakukan secara makroskopis dan mikroskopis.

Hasil: Hasil penelitian menunjukkan sebanyak 8 sampel (26,7\%) ditemukan jamur Candida $s p$ dan 22 sampel $(73,3 \%)$ tidak ditemukan jamur Candida sp. Sampel dengan jamur Candida $s p$, sebagian besar berasal dari penderita diabetes mellitus berjenis kelamin perempuan yaitu sebanyak 5 sampel $(16,3 \%)$.

Kesimpulan: Jamur Candida $s p$ dapat ditemukan dalam urine penderita diabetes mellitus terutama penderita dengan jenis kelamin perempuan. Hal ini dapat disebabkan oleh kondisi sistem kekebalan tubuh menurun, atau sering menggunakan pakaian ketat dari bahan sintetis.
\end{abstract}

Kata Kunci: Identifikasi, Candida sp, urine, penderita diabetes mellitus.

\section{Diterima 23 Oktober 2020; Accepted 30 Desember 2020}

\section{PENDAHULUAN}

Infeksi saluran kemih atau Urinary Tractus Infection (UTI) dapat disebabkan oleh berbagai macam patogen seperti bakteri, jamur, parasit, dan virus. Namun, jamur yang bersifat oportunistik lebih banyak berhubungan dengan kelainan yang terjadi pada saluran perkemihan. Infeksi jamur Candida sp memberikan gambaran kasus yang paling banyak penyebarannya dibandingkan dengan infeksi jamur lainnya (Esmailzadeh et al., 2018). Candida sp terutama Candida albicans dapat bersifat saprofit yaitu sebagai flora normal di kulit, selaput lendir mulut, saluran pencernaan, saluran pernapasan, vagina, dan kuku sedangkan sifat patogen dapat menimbulkan infeksi primer atau sekunder (Irianto, 2013).

Diabetes mellitus adalah kelainan metabolisme karbohidrat yang ditandai dengan meningkatnya kadar gula dalam darah. Gangguan metabolisme yang terjadi berhubungan dengan hormon insulin. Penderita seringkali tidak merasakan timbulnya gejala-gejala diabetes. Penyakit diabetes tidak dapat disembuhkan, namun dapat dilakukan pencegahan (Herlambang, 2013). Pasien diabetes mellitus tipe 2 cenderung mengalami berbagai infeksi. Kondisi hiperglikemia pada penderita DM rentan terkena infeksi jamur (Saskia and Mutiara, 2015). Kandidiasis merupakan penyakit menular yang dapat mempersulit pengendalian diabetes mellitus (Kamali, Sarvtin and Parsanasab, 2016).

Faktor-faktor predisposisi yang bisa mengubah sifat saprofit Candida $s p$ menjadi patogen yaitu penggunaan antibiotik yang secara tidak langsung merangsang pertumbuhan Candida sp. Diabetes mellitus dan kehamilan juga menjadi faktor predisposisi lainnya. Kadar gula dalam darah dan urine meningkat pada penderita diabetes sedangkan pada kehamilan terjadi kelebihan glikogen pada epitel vagina yang mengubah derajat keasaman dalam vagina menjadi lebih rendah dan merangsang pertumbuhan Candida $s p$. Kelembaban yang tinggi, misalnya penggunaan pakaian yang berbahan nilon atau wol, dan keringat yang 
berlebihan dapat meningkatkan risiko infeksi jamur Candida sp (Irianto, 2013).

Penderita diabetes mellitus dapat mengalami infeksi jamur disebabkan mekanisme pertahanan alami tubuh rendah. Komplikasi yang berhubungan dengan diabetes meningkatkan risiko infeksi, dan meningkatnya kadar gula dalam darah, jaringan, dan urine. Penderita diabetes mellitus perempuan mempunyai kadar glukosa ekstra dalam dinding vagina. Glukosa dalam urine tertumpuk pada vulva sehingga menyediakan makanan untuk pertumbuhan jamur. Daerah genetalia merupakan habitat ideal untuk pertumbuhan jamur (Indrayati, Suraini and Afriani, 2018).

Kandiduria dapat menyebabkan beberapa komplikasi serius pada pasien yang rentan sehingga penanganan dan penatalaksanaan kandiduria pada individu yang rentan termasuk penderita diabetes mellitus dapat menurunkan kemungkinan terjadinya komplikasi. Hal ini karena jumlah Candida $s p$ dalam urine dapat memberikan gambaran terkait kondisi kontaminasi dan penyebarannya pada saluran kemih dan organ ginjal (Esmailzadeh et al., 2018).

Kandiduria berfungsi sebagai penanda kandidemia diseminata yang dikaitkan dengan angka mortalitas 30-40\%. Spesies Candida dapat menuju ke saluran kemih melalui kolonisasi di uretra (jalur infeksi retrogade) namun dapat menuju saluran kemih bagian atas (Gajdács et al., 2019). Infeksi saluran kemih (ISK) sering terjadi pada individu dengan diabetes. Kandiduria menjadi gejala awal terjadinya penyebaran infeksi. Candida $s p$ adalah spesies yang dominan mengakibatkan terjadinya kandiduria (Falahati et al., 2016). Penelitian ini bertujuan untuk mengetahui keberadaan jamur Candida sp dalam urine penderita diabetes mellitus.

\section{METODE}

Penelitian ini adalah penelitian deskriptif dengan desain penelitian cross sectional. Penelitian ini dilaksanakan di Puskesmas Ngemplak 2 Kabupaten Sleman Yogyakarta sebagai tempat pengambilan sampel penelitian. Pemeriksaan identifikasi jamur Candida $s p$ dilakukan di Laboratorium Klinik STIKES Guna Bangsa Yogyakarta.

Populasi penelitian ini adalah pasien diabetes mellitus peserta program pengelolaan penyakit kronis (prolanis) yang melakukan pemeriksaan gula darah secara rutin di Puskesmas Ngemplak 2 Kabupaten Sleman Yogyakarta. Sampel adalah semua pasien peserta prolanis dengan diabetes mellitus tipe 2 yang melakukan pemeriksaan gula darah pada bulan Juli 2019. Jumlah sebanyak 30 sampel. Teknik pengambilan sampel adalah accidental sampling.

Bahan pemeriksaan yang digunakan dalam penelitian ini adalah urine sewaktu. Urin sewaktu adalah urin yang dikeluarkan pada satu waktu yang tidak ditentukan dengan khusus. Urin sewaktu ini biasanya cukup baik untuk pemeriksaan rutin (Gandasoebrata, 2010). Pengambilan spesien urine dilakukan setelah mendapatkan surat ijin penelitian dari Badan Kesbangpol Pemerintah Kabupaten Sleman dengan Nomor: 070/Kesbangpol/1978/2019 serta persetujuan dari responden melalui informed consent. Subjek juga diminta melengkapi kuesioner berisi karakteristik subjek penelitian. Spesimen urine yang telah dikumpulkan dalam pot (wadah) dibawa ke laboratorium klinik STIKES Guna Bangsa menggunakan cool box untuk dilakukan pemeriksaan identifikasi jamur Candida $s p$.

Spesimen urine ditanam pada media Sabaroud Dextrose Agar (SDA) menggunakan kapas steril, kemudian diinkubasi selama 1 minggu pada suhu $25^{\circ} \mathrm{C}$. Pembuatan media SDA (plate) dilakukan dengan cara melarutkan sebanyak 65 gram bubuk SDA dalam $1 \mathrm{~L}$ aquades kemudian dipanaskan dalam air mendidih dan aduk hingga semua bubuk SDA larut. Larutan SDA yang telah homogen lalu disterilkan dengan autoklaf selama 15 menit pada suhu $121^{\circ} \mathrm{C}$ dan selanjutnya dituang pada plate.

Pertumbuhan jamur diamati secara makroskopis berdasarkan ciri-ciri koloni Candida $s p$ yaitu berbentuk yeast atau ragi berwarna putih kekuningan, berbau asam, permukaan koloni basah dan cembung. Apabila tidak didapatkan pertumbuhan jamur pada media SDA (negatif), maka pemeriksaan secara mikroskopis tidak dilakukan. Pemeriksaan mikroskopis menggunakan pewarnaan Gram dilakukan jika didapatkan pertumbuhan jamur pada media SDA yang diduga sebagai Candida sp (Mutiawati, 2016).

Prosedur pewarnaan Gram dilakukan dengan cara menyiapkan kaca objek. Larutan $\mathrm{NaCl}$ fisiologis diambil sebanyak 1-3 ose menggunakan ose steril, diletakkan pada bagian tengah kaca objek. Koloni yang diduga jamur Candida sp diambil menggunakan ose steril dan diletakkan dalam larutan $\mathrm{NaCl}$ fisiologis pada kaca objek kemudian dicampur, diratakan dan dikeringkan di atas nyala api spritus serta difiksasi sebanyak 3 kali. Sediaan yang sudah kering diletakkan pada jembatan pengecatan dan diwarnai dengan pewarna Gram. Gram A diteteskan sebanyak 1-2 tetes pada sediaan, ditunggu hingga 1 menit lalu dibilas 
dengan air mengalir. Sediaan digenangi dengan 1-3 tetes Gram B, ditunggu hingga 1 menit lalu dibilas dengan air mengalir. Selanjutnya, Gram C diteteskan sebanyak 1-3 tetes pada objek glass dan ditunggu selama 30 detik kemudian dibilas dengan air mengalir. Sediaan kemudian ditetesi dengan 1-3 tetes Gram D dan ditunggu selama 30 detik lalu dibilas dengan air mengalir. Sediaan dikeringkan dan diamati dengan mikroskop binokuler menggunakan lensa objektif 40x dan 100x. Penelusuran data identitas subjek penelitian meliputi usia, jenis kelamin, dan pekerjaan. Data dianalisis secara deskriptif kemudian hasil disajikan dalam bentuk tabel, gambar, dan narasi.

\section{HASIL}

Sampel yang diperiksa sebanyak 30 subjek penelitian dengan jumlah 10 orang $(33,3 \%)$ berjenis kelamin laki-laki dan 20 orang $(66,7 \%)$ perempuan. Persentase terbesar berdasarkan karakteristik usia sebanyak 12 orang (40\%) pada usia 56-65 tahun dan pekerjaan yang dominan adalah petani dan IRT masing-masing sejumlah 11 orang $(36,7 \%)$.

Tabel 1. Karakterisik Subjek Penelitian Berdasarkan Usia, Jenis Kelamin dan Pekerjaan

\begin{tabular}{lcc}
\hline \multicolumn{1}{c}{ Karakteristik } & Jumlah & Persentase (\%) \\
\hline Usia & 7 & 23,3 \\
$46-55$ tahun & 12 & 40,0 \\
$56-65$ tahun & 11 & 36,7 \\
$>65$ tahun & & \\
Jenis kelamin & 10 & 33,3 \\
Laki-laki & 20 & 66,7 \\
Perempuan & & \\
Jenis pekerjaan & 2 & 6,6 \\
Wiraswasta & 11 & 36,7 \\
Petani & 11 & 36,7 \\
IRT & 1 & 3,3 \\
Pengemudi & 2 & 6,7 \\
Pensiun & 3 & 10,0 \\
Buruh Tani & &
\end{tabular}

Hasil pengamatan secara makroskopis terhadap media SDA sebagai media pertumbuhan jamur menunjukkan bahwa 9 dari 30 sampel positif (30\%) ditemukan jamur Candida sp, dengan ciri-ciri koloni berwarna putih kekuningan, berbau asam, koloni berbentuk ragi, permukaan koloni basah dan cembung.

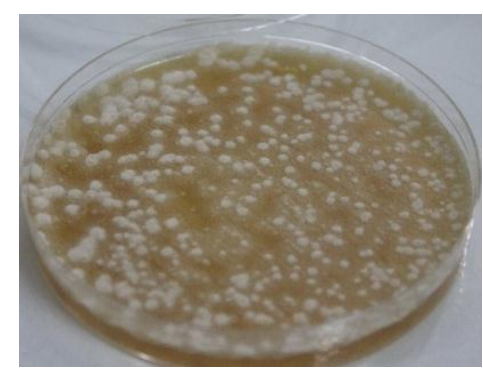

Gambar 1. Koloni Jamur Candida sp pada media SDA setelah inkubasi 1 minggu (Sumber: Data primer)

Hasil pemeriksaan makroskopis didapatkan 9 sampel positif didapatkan jamur tumbuh pada media SDA dengan ciri makroskopis Candida sp. Sampel dengan hasil pemeriksaan positif tersebut dilanjutkan 
dengan pemeriksaan mikroskopis. Hasilnya terdapat 8 sampel positif teridentifikasi sebagai Candida $s p$. Sampel positif ini ditunjukkan dengan adanya sel ragi (blastosfora) yang berbentuk oval dengan dominasi warna ungu pada gambar 2. Berdasarkan pemeriksaan makroskopis dan mikroskopis sampel urine dengan Candida sp adalah 8 sampel (26,7\%).

Tabel 2. Hasil Identifikasi Candida $s p$ dalam Urine Penderita Diabetes Mellitus

\begin{tabular}{cccc}
\hline No & Hasil Pemeriksaan Identifikasi Jamur Candida $\boldsymbol{s} \boldsymbol{p}$ & Jumlah & Persentase (\%) \\
\hline 1 & Positif & 8 & 26,7 \\
2 & Negatif & 22 & 73,3 \\
& Jumlah & 30 & 100,0 \\
\hline
\end{tabular}

Tabel 2 menunjukkan dari 30 sampel urin pasien penderita Diabetes Mellitus yang diperiksa, didapatkan sebanyak 8 sampel $(26,7 \%)$ terdapat jamur Candida $s p$ dan ditemukan 22 sampel $(73,3)$ tidak terdapat jamur Candida sp. Dari 8 sampel positif, sebanyak 5 sampel $(62,5 \%)$ diantaranya adalah urine penderita Diabetes mellitus berjenis kelamin perempuan.

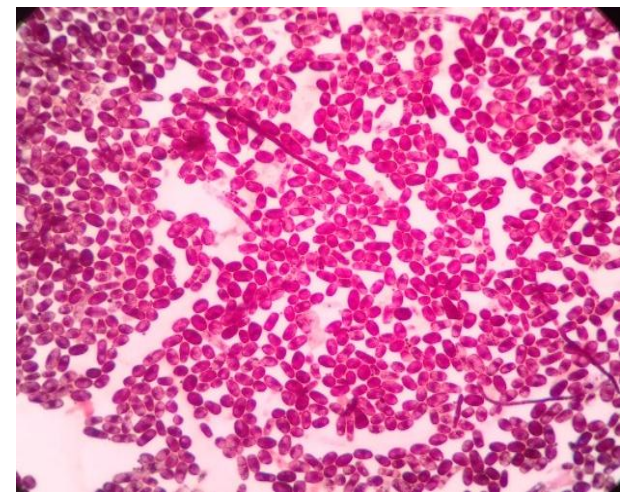

Gambar 2. Jamur Candida sp pada pewarnaan gram diperiksa dengan lensa objektif 100x (Sumber: Data primer)

\section{PEMBAHASAN}

Hubungan antara Diabetes mellitus dan kandidiasis telah banyak dipelajari terutama karena adanya peningkatan tingkat kerentanan pasien Diabetes mellitus terhadap infeksi jamur dibandingkan dengan yang tidak menderita DM. Mekanisme DM terkait Candida $s p$ tergantung pada infeksi lokal atau sistemik. Kondisi host yang rentan menyebabkan kolonisasi Candida berakibat infeksi lanjut yang ditandai dengan adhesi jamur ke permukaan sel epitel, kadar glukosa saliva yang lebih tinggi, aliran saliva berkurang, degenerasi mikrovaskuler, dan gangguan aktifitas neutrofil dikarenakan kandidiasis (Rodrigues, Rodrigues and Henriques, 2019).

Candida albicans adalah spesies yang umum didapatkan dari pasien kandidiasis. Namun, dikarenakan adanya peningkatan resistensi terhadap obat anti jamur, spesies non-Candida albicans juga ditemukan sebagai penyebab kandiduria antara lain $C$ glabrata, $C$ krusei, $C$ parapsilosis, dan $C$ tropicalis (Gharaghani et al., 2018). Semua spesies Candida tersebut mampu menyebabkan ISK (Yashavanth et al., 2013).

Hasil penelitian ini menunjukkan bahwa dari 30 sampel yang diperiksa terdapat 8 sampel (26,7\%) yang teridentifikasi Candida sp dalam urine yang diperiksa, sedangkan 22 sampel $(73,3 \%)$ tidak terdapat Candida sp. Penelitian Indrayati, dkk (2018), terdapat 3 sampel (14\%) dari total sebanyak 22 sampel urine Penderita Diabetes mellitus di Rumah Sakit Umum Daerah dr. Rasidin Padang yang didapatkan positif ditemukan Candida sp. Sampel yang digunakan adalah urine pasien penderita Diabetes Mellitus yang dirawat di RSUD dr. Rasidin Padang dari tanggal 22 Maret-Mei 2018 (Indrayati, Suraini and Afriani, 2018).

Pemeriksaan terhadap 31 sampel urine penderita DM di RSUD Ahmad Yani Kota Metro secara makroskopis pada media SDA, mikroskopis dengan pewarna Gram, dan uji spesifik Candida albicans pada media Germ-tube didapatkan 6 sampel $(19,4 \%)$ positif jamur Candida albicans dan 25 sampel $(80,6 \%)$ 
negatif (Rani and Wantini, 2016). Nilai persentase hasil positif tersebut lebih sedikit dibandingkan penelitian yang dilakukan peneliti, namun hasil identifikasi penelitian peneliti tidak menggunakan uji spesifik Candida albicans, sehingga belum dapat diidentifikasi secara spesies.

Penelitian Yismaw, et.al (2013) mendapatkan hasil sebanyak 7,5\% kandiduria didapatkan pada pasien Diabetes mellitus tanpa gejala dan 17,1\% pada pasien Diabetes mellitus dengan gejala. Candida $s p$ diisolasi dari 38 sampel urine. Spesies yang dominan ditemukan menginfeksi adalah Candida albicans $(42,0 \%)$ diikuti oleh $C$ glabrata $(34,2 \%)$ dan $C$ tropicalis $(15,8 \%)$. Kandiduria pada pasien Diabetes mellitus mempunyai hubungan kuat secara signifikan dengan karateristik jenis kelamin perempuan (Yismaw et al., 2013). Hal ini sejalan dengan penelitian yang dilakukan oleh peneliti karena dari hasil penelitian yang dilakukan didapatkan Candida $s p$ lebih banyak ditemukan dalam urine pasien Diabetes mellitus berjenis kelamin perempuan dibandingkan laki-laki dengan persentase 62,5\%. Jamur tumbuh lebih cepat pada perempuan karena kebersihan tubuh yang mungkin kurang terjaga, kondisi sistem kekebalan tubuh menurun, atau sering menggunakan pakaian ketat dari bahan sintetis. Kandidiasis vaginalis merupakan penyakit yang bersifat kompleks, artinya penyebab dan yang mendukung terjadinya penyakit ini tidak hanya satu faktor tetapi lebih dari satu faktor. Pemakaian alat kontrasepsi, keketatan celana, jenis bahan dari celana dalam dan higien alat genetalia merupakan faktor resiko penyakit kandidiasis vaginalis (Irianto, 2013).

Meskipun beberapa penelitian menyebutkan Candida albicans merupakan spesies utama penyebab kandiduria termasuk pada pasien DM, peningkatan prevalensi kandiduria karena spesies Candida nonalbicans ditunjukkan oleh beberapa penelitian seperti penelitian Falahati M, et al (2016). Hasil penelitian tersebut menunjukkan dari 305 kasus DM, sebanyak 38 orang $(12,5 \%)$ teridentifikasi Candida $s p$ dalam urine. Spesies yang teridentifikasi paling banyak adalah $C$ glabrata (50\%), C albicans $(31,6 \%), C$ krusei (10,5\%), C tropicalis (5,3\%), dan C kefyr (2,6\%) (Falahati et al., 2016).

Jamur Candida sp hidup sebagai flora normal namun pertumbuhan Candida $s p$ yang berlebihan dapat menyebabkan berkembangnya jamur menjadi organisme patogen. Candida albicans pada genetalia dapat menimbulkan balanitis pada pria dan vulvo-vaginitis pada wanita yang ditandai dengan peradangan pada mukosa, vulva dan vagina disertai dengan gatal-gatal, nyeri dan rasa panas. Apabila sudah parah dapat menyebabkan kandidiosis sistemik yaitu Candida $s p$ terbawa oleh aliran darah ke banyak organ. Penularan kandidiasis pada umumnya ditularkan melalui hubungan seksual dan penularan dari ibu ke bayi yang dilahirkannya. Peningkatan kadar glukosa dalam urin pada penderita Diabetes mellitus merangsang pertumbuhan jamur. Angka $\mathrm{pH}$ urin yang rendah karena adanya glukosa yang meningkat juga merangsang pertumbuhan jamur, serta meningkatkan frekuensi buang air kecil sehingga membuat daerah genetalia menjadi lebih lembab dan mempercepat pertumbuhan jamur (Irianto, 2013).

Penelitian tentang kandiduria pada penderita DM perlu untuk dilakukan penelitian lebih lanjut termasuk uji spesifik terhadap spesies jamur Candida $s p$ pada penderita DM. Hal ini penting untuk pencegahan dan penatalaksanaan penyebaran infeksi akibat jamur Candida $s p$ yang tidak lagi bersifat saprofit namun menjadi patogen sebagaimana dapat terjadi pada pasien DM.

\section{KESIMPULAN}

Jamur Candida $s p$ dapat ditemukan dalam urine penderita Diabetes mellitus terutama penderita dengan jenis kelamin perempuan.

\section{REFERENSI}

Esmailzadeh, A. et al. (2018) 'High prevalence of candiduria due to non-albicans Candida species among diabetic patients: A matter of concern?', Journal of Clinical Laboratory Analysis, 32(4), pp. 1-5. doi: $10.1002 /$ jcla.22343.

Falahati, M. et al. (2016) 'Characterization and identification of candiduria due to Candida species in diabetic patients', Current Medical Mycology, 2(3), pp. 10-14. doi: 10.18869/acadpub.cmm.2.3.10.

Gajdács, M. et al. (2019) 'Epidemiology of candiduria and Candida urinary tract infections in inpatients and outpatients: Results from a 10-year retrospective survey', Central European Journal of Urology, 72(2), pp. 209-214. doi: 10.5173/ceju.2019.1909.

Gandasoebrata, R. (2010) Penuntun Laboratorium Klinik. Jakarta: Dian Rakyat.

Gharaghani, M. et al. (2018) 'Candiduria; a review article with specific data from Iran', Turkish Journal of Urology, 44(6), pp. 445-452. doi: 10.5152/tud.2018.54069. 
Herlambang (2013) Menaklukkan Hipertensi dan Diabetes. Jakarta Selatan: Tugu Publisher.

Indrayati, S., Suraini, S. and Afriani, M. (2018) 'Gambaran Jamur Candida sp dalam Urine Penderita Diabetes Mellitus di RSUD dr. Rasidin Padang', Jurnal Kesehatan Perintis (Perintis's Health Journal), 5(1), pp. 46-50. doi: 10.33653/jkp.v5i1.93.

Irianto, K. (2013) Parasitologi Medis (Medical Parasitology). Bandung: Alfabeta.

Kamali, M., Sarvtin, M. T. and Parsanasab, H. (2016) 'Prevalence of Candida infection in patients with type 2 diabetes mellitus in Sari, North of Iran', Biomedical and Pharmacology Journal, 9(2), pp. 731734. doi: $10.13005 / \mathrm{bpj} / 996$.

Mutiawati, V. K. (2016) 'Pemeriksaan Mikrobiologi pada Candida albicans', Jurnal Kedokteran Syaih Kuala, 16(1), pp. 53-63. doi: 10.1214/aop/1176991250.

Rani, T. S. and Wantini, S. (2016) 'Gambaran Jamur Candida albicans Dalam Urine Penderita Diabetes Mellitus Di RSUD Jendral Ahmad Yani Kota Metro’, Jurnal Analis Kesehatan, 5(1), pp. 561-565.

Rodrigues, C. F., Rodrigues, M. E. and Henriques, M. (2019) 'Candida sp. Infections in Patients with Diabetes Mellitus', Journal of Clinical Medicine, 8(1), p. 76. doi: 10.3390/jcm8010076.

Saskia, T. I. and Mutiara, H. (2015) 'Infeksi Jamur pada Penderita Diabetes Mellitus', Majority (Medical Journal of Lampung University), 4(8), pp. 69-74.

Yashavanth, R. et al. (2013) 'Candiduria: Prevalence and trends in antifungal susceptibility in a tertiary care hospital of Mangalore', Journal of Clinical and Diagnostic Research, 7(11), pp. 2459-2461. doi: 10.7860/JCDR/2013/6298.3578.

Yismaw, G. et al. (2013) 'Prevalence of candiduria in diabetic patients attending Gondar University Hospital, Gondar, Ethiopia', Iranian Journal of Kidney Diseases, 7(2), pp. 102-107. 